\title{
LIFE HISTORIES OF NORTH AMERICAN GEOMETRIDAE.-LVI.
}

\author{
BY HARRISON G. DYAR, WASHINGTON, D. C.
}

Sciagraphia granitata Guenee. A mature larva was described by me as this species (Ent. news, v, 63, rS9.5) under the determination of the late Dr. Hulst. This is apparently an error, but I cannot now find the specimen on which Dr. Hulst made the determination. It does not appear in the National Museum series of granitata.

Eggs were obtained from captive females at Kaslo, British Columbia. The larvae fed on spruce, choosing the needles of the previous year which they closely matched by their dark bluish green color.

Egg. Elliptical, rounded, the ends very nearly alike, no distinct truncation; well flattened but without any flat areas; reticulations coarse, distinct, raised, hexagonal, the cell areas concave, resembling a thimble, about alike all over. Sordid bluish green; size $.8 \times .6$ $\times .4 \mathrm{~mm}$. Hatched in six days.

Stage $I$. Head bilobed, full, sutures depressed, bright orange, shining. Body moderate, a little flattened, normal; pale yellow, translucent, green from the food, no markings; anal feet project laterally, segments coarsely annulate; tubercles elevated, concolorous; setae pale, rather short, capitate.

Stage II. Head luteous, eye black, mouth brown; width $.5 \mathrm{~mm}$. Body moderate, rather stout, sordid green, the dorsum with very fine, obscure, grayish olivaceous longitudinal lines; a broad stigmatal whitish band, not contrasted; venter lined like the dorsum; feet blackish except the anal pair. Tubercles small, blackish; setae short, dark.

Stage III. Head rounded, flat before, a little higher than joint 2 , whitish luteous, the sutures dark: width $.8 \mathrm{~mm}$. Body moderate, not elongate, blackish green with a broad white stigmatal stripe. Ground color olivaceous with blackish dotted geminate dorsal, subdorsal, lateral, substigmatal, subventral and medioventral lines. Thoracic feet blackish, the abdominal ones olivaceous. Tubercles small, black, in pale rings; setae rather long, dusky.

Stage IV. Head smoothly rounded, clypeus level, luteous green, a broad smoky black band at sides above, brownish before eyes; ocelli in a whitish field, labium blackish shaded; width I.2 mm. Body moderate, not elongated, feet normal; dark green, heavily shaded with blackish. Dorsal and subdorsal lines narrow, whitish, the sides more heavily black shaded; stigmatal line broad, white, diffusely edged; illy defined pale subventral and medioventral lines, both narrow. Feet blackish ; tubercles small, dark, obscure; setae dusky.

Stage $V$. Head rounded, slightly bilobed, clypeus level, broad; shining bluish green with a very broad band of black on the sides of the lobes, a little checkered in brown on its edges; width $1.8 \mathrm{~mm}$. Body cylindrical, moderate, normal, smooth; bluish green like the old spruce needles, shaded with white; a white addorsal border to the dorsal vessel; white subdorsal lines, faint at the ends, both greenish white, not contrasted; an irregularly motrled triplicate black lateral band, touching the lower edge of the subdorsal line, not reaching the faint white, diffuse stigmatal line. A similar, less distinct triplicate subventral band, touching a faint white, ventral line. Thoracic feet brown, those of joint ro green, of joint 13 black shaded. Tubercles concolorous, obsolete, setae rather long, black. Later olivaceous blackish spots show distinctly on joints 6 to 8 in the substigmatal band.

The larvae entered earth to pupate early in July: no moths emerged. 



Submit your manuscripts at

http://www.hindawi.com
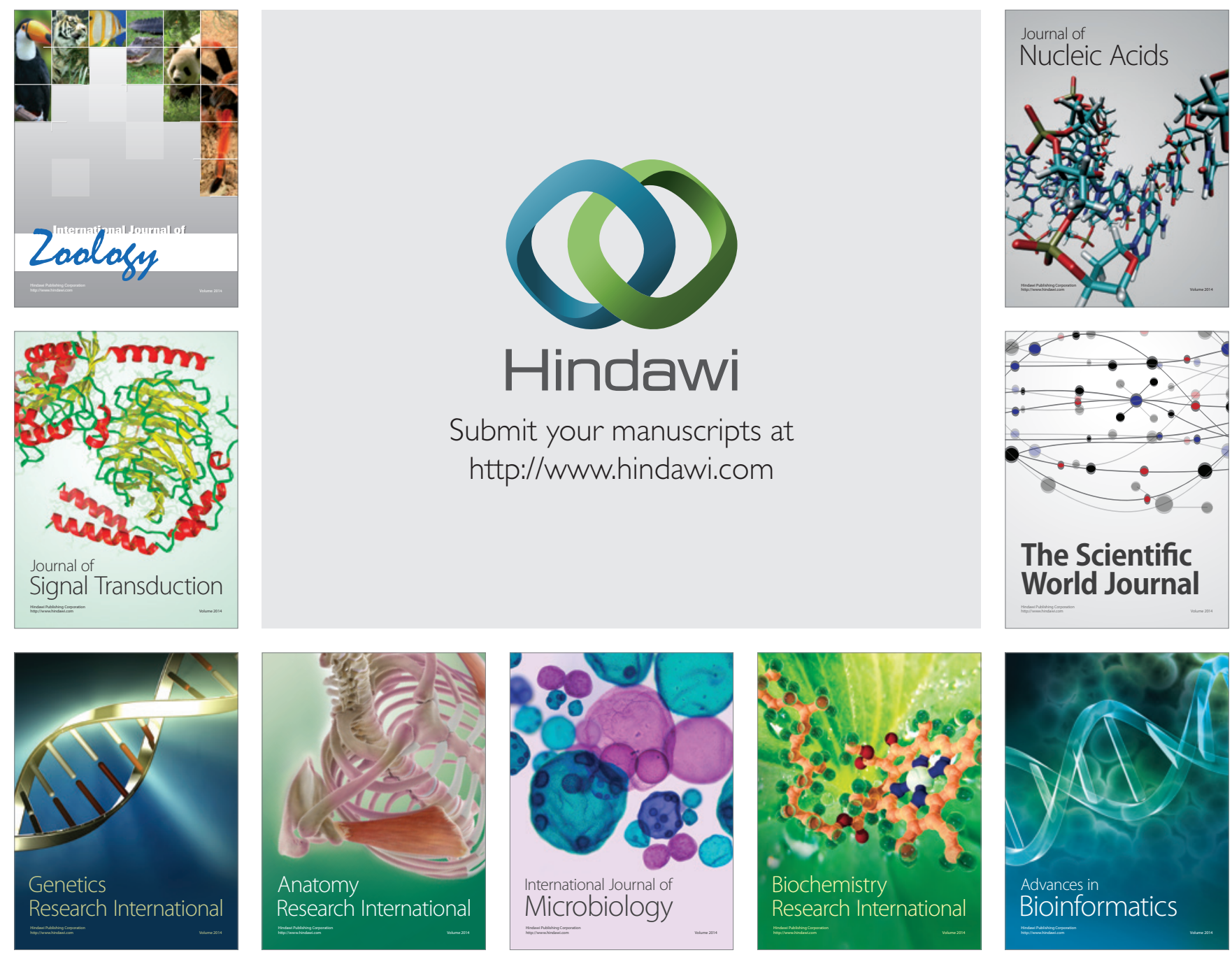

The Scientific World Journal
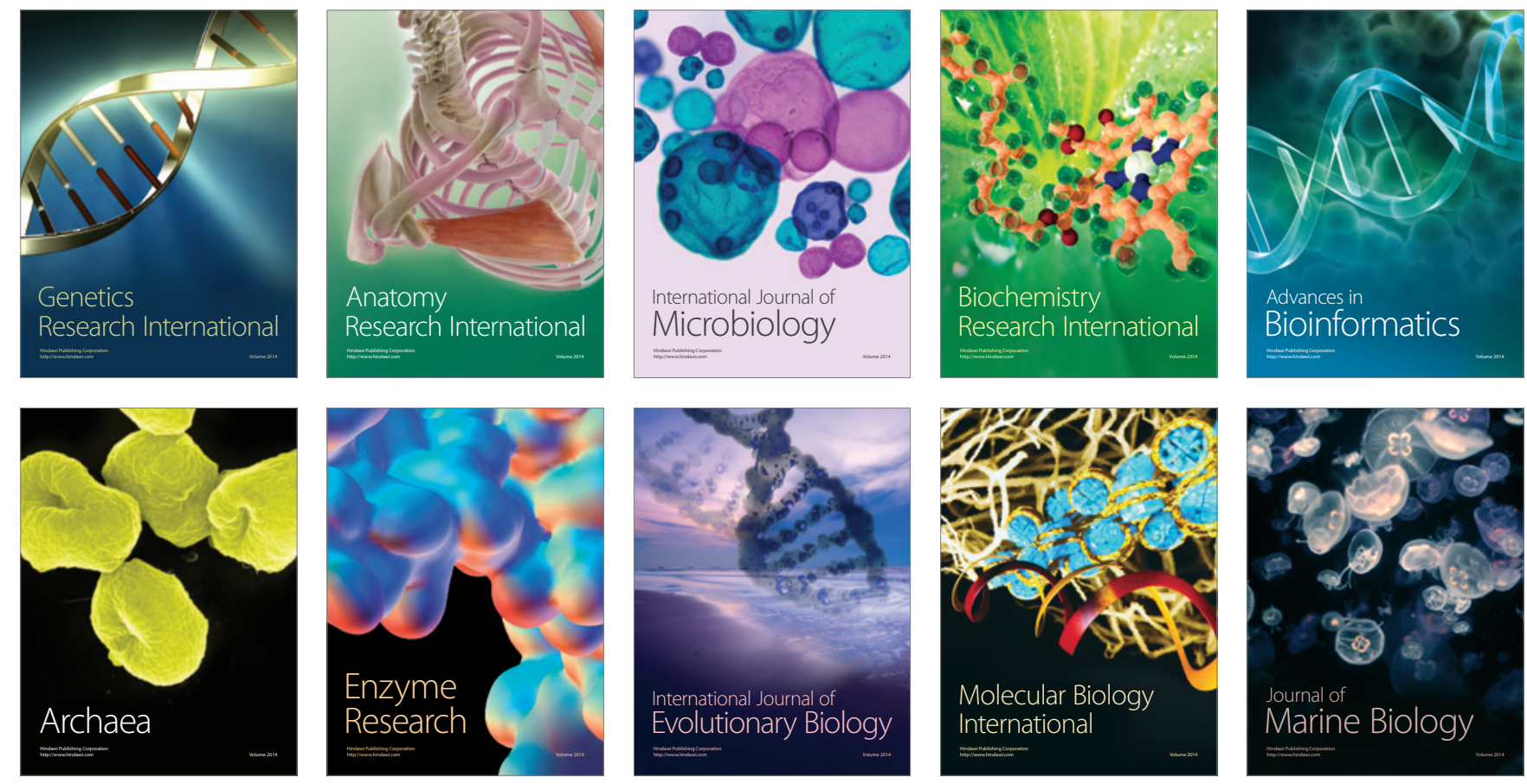